\title{
ПРОБЛЕМИ ВИКЛАДАННЯ ДИСЦИПЛІНИ “ОРГАНІЧНА ХІМІЯ” ДЛЯ СТУДЕНТІВ ФАРМАЦЕВТИЧНОГО ФАКУЛЬТЕТУ, ЩО НАВЧАЮТЬСЯ ЗА НАПРЯМКОМ “ТЕХНОЛОГІЯ ПАРФУМЕРНО- КОСМЕТИЧНИХ ЗАСОБІВ"
}

\author{
О. Ю. Воскобойнік
}

Запорізький державний медичний університет

\author{
PROBLEMS OF TEACHING OF "ORGANIC CHEMISTRY" \\ FOR STUDENTS OF PHARMACEUTICAL DEPARTMENTS, \\ WHICH ARE TRAINING IN AREA "TECHNOLOGY OF PERFUMERY \\ AND COSMETIC REMEDIES"
}

O. Yu. Voskoboynik

\author{
Zaporizhzhia State Medical University
}

\begin{abstract}
У представленій роботі описані основні проблеми, з якими стикаються викладачі при викладанні органічної хімії студентам фармацевтичних факультетів, які навчаються за напрямком "Технологія парфумерно-косметичних препаратів". Проведено порівняльний аналіз навчальних планів, за якими навчаються студенти спеціальностей “Фармація” та "Технологія парфумерно-косметичних засобів". Запропоновані можливі шляхи удосконалення навчального процесу органічної хімії студентам фармацевтичних факультетів, які навчаються за напрямком "Технологія парфумерно-косметичних препаратів".
\end{abstract}

The main problems of teaching of "Organic chemistry" for students of pharmaceutical departments, which are training in area "Technology of Perfumery and Cosmetic Remedies" were discussed in presented article. The comparison of curriculums for students which are training in areas "Pharmacy" and "Technology of Perfumery and Cosmetic Remedies" was conducted. The possible ways of improvement of teaching of "Organic chemistry" for students of pharmaceutical departments, which are training in area "Technology of Perfumery and Cosmetic Remedies" were proposed.

Вступ. Підготовка фахівців за спеціальністю “Технологія парфумерно-косметичних засобів" $\epsilon$ відносно новим напрямком надання освітніх послуг вищими медичними навчальними закладами. Виникнення зазначеної спеціальності, на нашу думку, було обумовлено більшою мірою попитом на ринку освітніх послуг, аніж реально існуючим ринком праці. Адже, незважаючи на той факт, що ринок надання косметичних послуг на той час був сформований та мав стійку тенденцію до розширення, підприємства, що надавали зазначені послуги на високому професійному рівні, були зацікавлені у залученні фахівців виключно з вищою медичною освітою (як правило, лікарів-дерматологів). Лобісти створення зазначеного напряму підготовки припускали, і небезпідставно, що рано чи пізно сформується група абітуріснтів, яка буде орієнтована на роботу в організаціях, які надають кос-

(c) О. Ю. Воскобойнік метичні послуги, однак 3 тих чи інших міркувань не планують здобувати вищу освіту за напрямком “Лікувальна справа". Зазначена цільова аудиторія була би зацікавлена у здобутті спеціалізованої “косметологічноі”" підготовки, особливо в поєднанні з дипломом вищого навчального закладу системи МОЗ України. Для задоволення даного попиту і було вирішено створити відповідну спеціальність шляхом модифікації існуючої програми підготовки спеціалістів кваліфікації “провізор". Результатом даної роботи стала освітня програма підготовки за спеціальністю "Технологія парфумерно-косметичних засобів”. Потенційні абітурієнти сприймали напрям “Технологія парфумерно-косметичних засобів" як такий, що орієнтований на підготовку кадрів для установ, спеціалізованих на наданні косметичних послуг. Частково сподівання були виправдані, адже до програми підготовки включені дисципліни, які безпосередньо пов'язані з проведенням косметичних процедур, наприклад апаратна 
косметологія. Водночас програмою підготовки студентів за спеціальністю “Технологія парфумерно-косметичних засобів" передбачено значний обсяг дисциплін суто хімічного та технологічного спрямування, при вивчанні яких у студентів виникає багато проблем. Зазначені проблеми пов'язані як $з$ недостатністю базових знань, так і з відсутністю мотивації до вивчення хімічних та технологічних дисциплін студентами, орієнтованими на "індустрію краси".

Основна частина. Метою представленої роботи було виявлення першопричин низького рівня засвоє- ння знань 3 дисципліни “Органічна хімія” у зазначеній категорії студентів та огляд основних напрямків вирішення зазначеної проблеми. Для реалізації даної мети нами було проведено порівняння кількості годин, які виділяються на вивчення хімічних дисциплін для студентів, що навчаються за спеціальностями “Фармація" та "Технологія парфумерно-косметичних засобів" $[1,2]$. Як можна побачити $з$ представлених даних (табл. 1), об'єм навчального матеріалу 3 хімічних дисциплін у студентів, що навчаються за обома програмами, $є$ цілком порівнювальним.

Таблиця 1. Порівняння кількості кредитів та годин, присвячених вивченню хімічних дисциплін для студентів, які навчаються за спеціальностями “Фармація” та "Технологія парфумерно-косметичних засобів"

\begin{tabular}{|c|l|c|c|}
\hline № & Навчальна дисципліна & $\begin{array}{c}\text { Кількість кредитів/годин для } \\
\text { студентів, які навчаються за } \\
\text { спеціальністю } \\
\text { "Фармація" }\end{array}$ & $\begin{array}{c}\text { Кількість кредитів/годин для } \\
\text { студентів, які навчаються за } \\
\text { спеціальністю “Технологія } \\
\text { парфумерно-косметичних засобів” }\end{array}$ \\
\hline 1 & Неорганічна хімія & $8.5 / 306$ & $6 / 216$ \\
\hline 2 & Органічна хімія & $9 / 324$ & $9 / 324$ \\
\hline 3 & Аналітична хімія & $9 / 324$ & $9 / 324$ \\
\hline 4 & Фізична та колоїдна хімія & $5.5 / 198$ & $5 / 180$ \\
\hline 5 & $\begin{array}{l}\text { Фармацевтична хімія } \\
\text { (Фармацевтична та } \\
\text { косметична хімія) }\end{array}$ & $14.5 / 522^{*}$ & $15 / 540^{* *}$ \\
\hline 6 & Токсикологічна хімія & $6 / 216$ & - \\
\hline
\end{tabular}

Примітки: * вивчається протягом 3 та 4 років навчання;

** вивчається протягом 3,4 та 5 років навчання.

Принциповою відмінністю є відсутність у програмі підготовки спеціалістів за напрямком "Технологія парфумерно-косметичних засобів” такої дисципліни, як “Токсикологічна хімія". Несуттєві розбіжності спостерігаються у випадку “Неорганічної хімії” i “Фізичної та колоїдної хімії”, в даних випадках студенти, які навчаються за спеціальністю “Технологія парфумернокосметичних засобів", мають дещо менше навчальних годин у порівнянні зі студентами, які навчаються за спеціальністю “Фармація”. Певні відмінності є також при вивченні “Фармацевтичної/Косметичної хімії". В той самий час для вивчення “Органічної хімії” та “Аналітичної хімії” студентам обох спеціальностей виділяється однакова кількість годин, що, на перший погляд, $є$ досить дивним, з огляду на певні розбіжності у професійних обов'язках майбутніх випускників. Однак в даному випадку слід взяти до уваги, що згідно з діючим законодавством України студенти, які навчаються за спеціальністю “Технологія парфумерно-косметичних засобів", після успішного завершення ВНЗ цілком можуть працювати на про- візорських посадах в аптечних установах [3]. Водночас питання про готовність та бажання студентів сприймати такий обсяг хімічної інформації залишається відкритим.

З нашого досвіду, основні проблеми у засвоєнні курсу “Органічна хімія" студентами, які навчаються за спеціальністю “Технологія парфумерно-косметичних засобів", обумовлені низькою мотивацією студентів до вивчення зазначеної дисципліни та недостатнім рівнем адаптації робочої програми і навчального матеріалу.

Враховуючи, що запорукою якісної професійної підготовки є викладення матеріалу, який є максимально адаптованим для цільової аудиторії, нами пропонується певна корекція вмісту навчального матеріалу з органічної хімії. Загальноприйнятою навчальною програмою з органічної хімії для студентів фармацевтичного факультету передбачено тематики, в рамках яких студенти оволодівають знаннями з будови, фізико-хімічних та біологічних властивостей окремих класів органічних сполук (вуглеводні та їх галоге- 
новмісні похідні, спирти, альдегіди, гетероциклічні сполуки тощо). Звичайно, що аналогічна програма підходить для осіб, які навчаються за спеціальністю “Технологія парфумерно-косметичних засобів", але після певної модифікації. Відомо, що сполуки, які знаходять застосування в якості компонентів парфумерних композицій та косметичних засобів, є досить численною [4], та що важливо, представники зазначеної категорії речовин належать до різноманітних класів органічних сполук, що дозволяє використовувати їх для представлення в якості прикладів на заняттях 3 органічної хімії. Так, при вивченні хімічних властивостей альдегідів та кетонів в якості сполук, на прикладі яких будуть обговорені фізичні та хімічні властивості, бажано використати ті, що застосовуються при виготовленні парфумерної або косметичної продукції, наприклад октанон-3, діацетил, метилгептенон тощо. Аналогічний підхід можна використати при вивченні естерів (етилацетат, пропілацетат, пренілацетат), тіоаналогів етерів (дибутилсульфід), нітрилів (3-метилдодеканонітрил, тридеценонітрил) та гетероциклічних сполук (феніран, жиран, піноран). Використання

\section{Списоклітератури}

1. Про внесення змін до Навчального плану підготовки фахівців освітньо-кваліфікаційного рівня “спеціаліст” кваліфікації “провізор-косметолог” у вищих навчальних закладах IV рівня акредитації за спеціальністю “Технологія парфумерно-косметичних засобів”, затвердженого наказом МОЗ від 07.12.2009 р. № 932 : наказ МОЗ України від 08.07.2010 p. №544.

2. Про внесення змін до Навчального плану підготовки фахівців освітньо-кваліфікаційного рівня “спеціаліст” кваліфікації “провізор” у вищих навчальних закладах IV рівня акредитації за спеціальністю “Фармація”, затвердженого наказом МОЗ від 07.12.2009 р. № 930 : наказ МОЗ України від 08.07.2010 р. № 542 . представленого підходу дозволить значно підвищити мотивацію до вивчення дисципліни “Органічна хімія", адже студенти будуть чітко усвідомлювати асоційованість здобутих знань з їхньою майбутньою професією.

Також значно підвищити якість засвоєння знань 3 органічної хімії дозволить адаптація методичних посібників та вказівок для студентів, тим більше, що даний крок $є$ логічним продовженням описаної вище корекції вмісту навчального матеріалу. Необхідно створити методичні вказівки та посібники, в яких органічна хімія була викладена з позиції хімії сполук, що мають прикладне значення у парфумерній або косметичній технології, тим більше, що існують вдалі приклади схожих за змістом матеріалів [5].

Висновок. Усвідомлення описаних проблем та використання запропонованих у статті підходів дозволить, на нашу думку, значно покращити показники успішностіз дисципліни “Органічна хімія” у студентів, які навчаються за спеціальністю “Технологія парфумерно-косметичних засобів" та зробити зазначений предмет більш цікавим для цільової аудиторії.

3. Ткаченко Н. О. Юридичний статус провізора-косметолога / Н. О. Ткаченко, І. В. Бушеєва // Актуальні питання фармацевтичної та медичної науки та практики. - 2011. № 1. - С. $145-146$.

4. Войткевич С. А. 865 душистых веществ для парфюмерии и бытовой химии / С. А. Войткевич. - М. : Пищ. пром-сть, 1994. - 594 с.

5. Пешекерова М. С. Практические работы по органической химии с уклоном в химию терпенов / М. С. Пешекерова. - Л. : Госхимтехиздат, Ленинградское отделение, 1932. $-80 \mathrm{c}$. 